\title{
PEMBERDAYAAN KELUARGA MENJADI KELUARGA TANGGAP HIPERTENSI (LUGAS) DI DUSUN DURMO, DESA BANTUR, KECAMATAN BANTUR
}

\author{
Kurniawan Erman Wicaksono ${ }^{1}$, Ahmad Guntur Alfianto ${ }^{2}$ \\ Program Studi S1 Ilmu Keperawatan, Stikes Widyagama Husada Malang ${ }^{1,2}$ \\ email: wicaksono42137@gmail.com
}

\begin{abstract}
Hypertension is one of number one causes of death in the world. The prevalence of hypertension has increased every year along with increasing age, level of education, non-working status and high level of per capita expenditure. Malang Regency is one of the regions in Indonesia with the number one of hypertensive patients. Completion of hypertension problems in Malang Regency until now has not met the 100\% target. The lowest coverage achievement in Bantur District is in Bantur Village. This community service program aims to improve coverage by increasing family knowledge. Knowledge about health problems will affect the ability and independence of the family to become a hypertensive responsive family through socialization, counseling, and training given to families. Community service is carried out using 5 stages and methods, namely problem identification stage, needs analysis stage, program preparation stage, program implementation phase, and evaluation monitoring stage. The results of community service showed that the target families of 40 families were able to carry out five good family health tasks.
\end{abstract}

Key words: empowerment, family, responsive, hypertension

\section{PENDAHULUAN}

Hipertensi masih menjadi permasalahan di dunia dan negara berkembang. Hipertensi merupakan salah satu penyebab kematian nomor satu di dunia. Hasil Riset Kesehatan Dasar (RISKESDAS) tahun 2013 menunjukkan dalam data penyakit tidak menular, prevalensi hipertensi di Indonesia cenderung meningkat mencapai 26,5\% berdasarkan hasil pengukuran (Muhadi, 2016). Prevalensi hipertensi di Provinsi Jawa Timur meningkat 1\% dari tahun 2014 menjadi 15,16\% pada tahun 2015 (Dinas Kesehatan Provinsi Jawa Timur, 2015).

Kabupaten Malang merupakan salah satu daerah di Indonesia dengan jumlah penderita hipertensi menduduki peringkat pertama dengan prevalensi 27,4\%. Penyelesaian masalah hipertensi di Kabupaten Malang sampai saat ini belum memenuhi target $100 \%$. Lima wilayah dengan target capaian hipertensi rendah antara lain Kecamatan Bantur sebesar 7,208\%, Kecamatan Ampelgading sebesar $7,247 \%$, Kecamatan Gondanglegi sebesar 8,102\%, Kecamatan Tirtoyudo sebesar $8,360 \%$, dan Kecamatan Turen sebesar 8,382\%. Kecamatan Bantur merupakan kecamatan dengan target capaian paling rendah dengan capaian cakupan sebesar 
11,02\%. Capaian cakupan terendah di Kecamatan Bantur berada di Desa Bantur dengan angka cakupan 10,12\%. Capaian cakupan yang rendah menunjukkan kurangnya kesadaran masyarakat dalam memanfaatkan fasilitas pelayanan kesehatan dan rendahnya pengetahuan masyarakat tentang masalah kesehatan (Dinas Kesehatan Kabupaten Malang, 2016).

Pemberdayaan keluarga merupakan salah satu bentuk kegiatan yang merupakan strategi pembangunan kesehatan untuk merubah perilaku keluarga sebagai bagian terkecil dari masyarakat dalam mencegah masalah kesehatan (Kementerian Kesehatan Republik Indonesia, dalam Lestari, 2016). Pengabdian masyarakat ini menitikberatkan pada lima tugas kesehatan keluarga, antara lain keluarga mampu mengenal masalah kesehatan, keluarga mampu mengambil keputusan yang tepat dalam penanganan masalah kesehatan, keluarga mampu melakukan tindakan perawatan mandiri pada anggota keluarga yang sakit, keluarga mampu memodifikasi lingkungan sekitar anggota keluarga yang sakit, dan keluarga mampu memanfaatkan fasilitas pelayanan kesehatan terdekat (Rakhshan M, et.al., 2015).

\section{METODE PENELITIAN}

Program pengabdian kepada masyarakat dilaksanakan selama 3 bulan (JuliSeptember 2018) dengan menggunakan lima tahapan metode, yaitu:

1. Identifikasi masalah

Dosen, mahasiswa dan kader kesehatan wilayah bersama-sama mengidentifikasi dan permasalah yang terdapat di Desa Bantur Kecamatan Bantur khususnya masalah hipertensi.

2. Analisis kebutuhan

Keterlibatan seluruh keluarga di Desa Bantur dalam pelaksanaan dan diskusi yang akan menghasilkan kebutuhan dan perioritas program.

3. Penyusunaan program

Program yang menjadi priorits adalah memampukan dan memandirikan keluarga dalam melakukan pencegahan hipertensi pada anggota keluarga meliputi mampu mengenal masalah, mengambil keputusan, melakukan tindakan perawatan, memodifikasi lingkungan, dan memanfaatkan fasilitas layanan kesehatan.

4. Pelaksanaan program

Program akan dilaksanakan pada bulan Juli hingga September 2018. Pelaksanaan kegiatan program yang menjadi perioritas adalah memampukan keluarga mengenal masalah kesehatan khususnya hipertensi, memampukan keluarga mengidentifikasi masalah kesehatan hipertensi, memampukan keluarga melakukan perawatan pada anggota keluarga yang sakit hipertensi, memampukan keluarga dalam memodifikasi lingkungan bagi penderita 
hipertensi, serta memampukan keluarga dalam memanfaatkan fasilitas layanan kesehata terdekat, serta pelatihan kader keluarga LUGAS.

5. Monitoring dan Evaluasi

Monitoring dan evalusi akan dilaksanakan setiap satu minggu sekali selama program berjalan.

\section{HASIL PENELITIAN}

Waktu kegiatan dilaksanakan dalam rentang waktu dua bulan, yang dimulai dari Bulan Agustus sampai Bulan September 2018. Tempat kegiatan di Musholla Yayasan Nurul Huda Dusun Durmo, Desa Bantur, Kecamatan Bantur, Kabupaten Malang. Bentuk kegiatan ini terdiri dari 5 tahapan yaitu:

1. Tahap sosialisasi hipertensi

Tahap ini merupakan tahap awal kegiatan. Sosialisasi terkait hipertensi dilakukan kepada seluruh keluarga yang memiliki anggota keluarga hipertensi di wilayah Dusun Durmo, Desa Bantur. Isi sosialisasi terkait hipertensi meliputi pengetahuan bagi keluarga tentang konsep dasar hipertensi.

2. Tahap identifikasi masalah hipertensi

Setelah keluarga terpapar oleh pengetahuan terkait hipertensi, dilakukan penggalian ketidaktercapaian masalah kesehatan keluarga meliputi kemampuan keluarga dalam mengenal masalah kesehatan keluarga, kemampuan keluarga dalam mengambil keputusan yang tepat bagi anggota keluarga yang sakit, kemampuan keluarga dalam melakukan tindakan perawatan pada anggota keluarga yang sakit, kemampuan keluarga dalam memodifikasi lingkungan yang sehat, serta kemampuan keluarga dalam memanfaatkan fasilitas pelayanan kesehatan terdekat.

3. Tahap pelatihan tentang tindakan perawatan mandiri oleh keluarga

Setelah teridentifikasi masalah kesehatan keluarga terkait hipertensi, dilakukan pelatihan kepada keluarga tentang cara melakukan perawatan secara mandiri kepada anggota keluarga yang sakit.

4. Tahap Sosialisasi dan Pelatihan Modifikasi Lingkungan oleh Keluarga Bagi Penderita Hipertensi serta Sosialisasi Pemanfaatan Fasilitas Layanan Kesehatan

Setelah keluarga mampu secara mandiri melakukan tindakan perawatan, maka selanjutnya diberikan sosialisasi dan pelatihan tentang bagaimana cara memodifikasi atau mengkondisikan lingkungan sekitar keluarga agar menjadi lingkungan yang aman dan nyaman bagi penderita hipertensi dengan tujuan meningkatkan derajat kesehatan anggota keluarga yang menderita hipertensi.

5. Tahap pelatihan kader kesehatan LUGAS

Sebagai tindak lanjut, diberikan pelatihan khusus kepada para kader sebagai wujud pemberdayaan (empowerment) terkait dengan kompetensi keluarga LUGAS. 
Hasil analisis statistik perbedaan nilai pretest dan posttest masyarakat menunjukkan peningkatan signifikan.

Tabel 1: Hasil Analisis Statistik Perbedaan Nilai Pretest dan Posttest Keluarga

\begin{tabular}{lcc}
\multicolumn{1}{c}{ Aspek } & Pretest & Posttest \\
\hline Pengetahuan & 5,00 & 6,27 \\
Sikap & 3,63 & 4,45 \\
\hline Tindakan & 2,90 & 3,18 \\
\hline
\end{tabular}

Pengetahuan, sikap, dan tindakan responden tentang pencegahan hipertensi pada keluarga antara sebelum dan sesudah diberikan intervensi mengalami perbedaan yang signifikan. Menurut Andari (2014), pendidikan kesehatan merupakan suatu usaha menyampaikan pesan kesehatan kepada masyarakat, kelompok, atau individu. Tujuan penyampaian pesan adalah untuk meningkatkan pengetahuan, memperbaiki sikap kesehatan menjadi lebih baik dan diharapkan dapat berpengaruh terhadap perilaku. Pendidikan kesehatan menggunakan model pendekatan terhadap keluarga membuat keluarga (caregiver) mampu mengetahui pemenuhan kebutuhan mereka sendiri, mampu meningkatkan pemahaman tentang apa yang harus keluarga lakukan terhadap masalahnya dengan sumber daya yang ada ditambah dukungan dari luar, serta meningkatkan kemampuan dalam memutuskan tindakan yang tepat untuk meningkatkan derajat hidup sehat anggota keluarganya (Suerni, dkk., 2015).

\section{KESIMPULAN DAN SARAN}

Teridentifikasinya masalah terkait ketidakmampuan keluarga dalam menjalankan 5 tugas kesehatan keluarga. Setelah pengabdian masyarakat keluarga mampu mengenal masalah kesehatan keluarga terkait hipertensi, keluarga mampu mengambil keputusan saat ada anggota keluarga mengalami tanda dan gejala awal hipertensi, keluarga mampu memberikan tindakan perawatan pertama secara mandiri pada anggota keluarga yang mengalami hipertensi, keluarga mampu menciptakan lingkungan yang nyaman bagi anggota keluarga yang menderita hipertensi, serta keluarga mampu dalam memanfaatkan fasilitas pelayanan kesehatan terdekat sebagai langkah kuratif dan rehabilitatif.

\section{DAFTAR PUSTAKA}

Andari, I. 2014. Pengaruh Pendidikan Kesehatan dalam Model Peer Group terhadap Perilaku Ibu Melakukan Deteksi Dini kanker Serviks. http://eprints.ums.ac.id [13 Agustus 2018]

Dinas Kesehatan Kabupaten Malang. 2014. Profil Kesehatan Kabupaten Malang Tahun 2014. http://depkes.go.id [11 Juni 2018]

Dinas Kesehatan Kabupaten Malang. 2016. Profil Kesehatan Kabupaten Malang Tahun 2016. Malang: Dinas Kesehatan Kabupaten Malang 
Dinas Kesehatan Provinsi Jawa Timur. 2015. Profil Kesehatan Provinsi Jawa Timur Tahun 2015. Surabaya: Humas Dinkes Jatim

Rakhshan, M., Kordshooli, K. R., Ghadakpoor, S. 2015. Effects of Family-Center Empowerment Model on the Lifestyle of Heart Failure Patients: A Randomised Controlled Clinical Trial. IJCBNM Journal, 3 (4). Iran: Shiraz University of Medical Science

Suerni, T., Keliat, B., Helena, N. 2013. Penerapan Terapi Kognitif dan Psikoedukasi Keluarga pada Klien Harga Diri Rendah di Ruang Yudhistira RS Dr. H. Marzoeki Mahdi Bogor. Jurnal Keperawatan Jiwa, 1 (2). http://jurnal.unimus.ac.id [11 Agustus 2018]

Sugiarto, A. 2011. Faktor-Faktor Risiko Hipertensi pada Masyarakat. Jakarta: PT Gramedia Pustaka Utama 